\title{
Suton međunarodnog liberalnog poretka, dijalektika političke mehanike i novi Vestfalski sistem za 21. vek
}

\author{
NEVEN CVETIĆANIN, MARKO MANDIĆ \\ Institut društvenih nauka, Beograd
}

\begin{abstract}
Sažetak
Autori ovog rada nude pregled i analizu uspona i pada međunarodnog liberalnog poretka koji je nastao nakon okončanja Hladnog rata i uspona moći Sjedinjenih Američkih Država. Spoljnopolitička agenda jedine posthladnoratovske supersile vođena je idejom stvaranja globalnog poretka utemeljenog na ideologiji (globalnog) liberalizma koja u sebi inkorporira teorije liberalnog mira, demokratskog mira i neoliberalnog institucionalizma. Uspostavljanje tzv. globalnog liberalnog poretka dosada je bilo praćeno brojnim političkim, socijalnim, ekonomskim i bezbednosnim krizama, a trenutnu eru međunarodnih odnosa odlikuju uspon relativne moći "neliberalnih" globalnih aktera, pre svega Kine i Rusije, kao glavnih izazivača svetske dominacije Sjedinjenih Američkih Država, te geopolitički revizionizam i ideološka konfrontacija liberalnih i antiliberalnih snaga širom sveta. Autori ovog rada koriste specifičan analitički metod tzv. dijalektike političke mehanike, koji se oslanja na učenja Friedricha Hegela o dijalektici istorije i Carla Schmitta o fenomenu političkog, kako bi objasnili trenutnu dinamiku međunarodnih odnosa, pokazujući da političko polje "permanentno pulsira" što, u svemu što je društveno i političko, nužno kreira akciju i reakciju, čijom dinamikom se mogu tumačiti i globalna zbivanja kojima upravo prisustvujemo.

Ključne riječi: međunarodni liberalni poredak, dijalektika političke mehanike, prijatelj/neprijatelj, međunarodni odnosi, Vestfalski sistem
\end{abstract}

\section{Uvod}

U poslednje tri decenije svedoci smo izrazito dinamične prirode međunarodnih odnosa i usložnjavanja strukture sveta u kojem živimo. ${ }^{*}$ Od kraja Hladnog rata i pa-

* Rad je napisan u okviru Programa istraživanja Instituta društvenih nauka za 2020. godinu koji podržava Ministarstvo prosvete, nauke i tehnološkog razvoja Republike Srbije. 
da bipolarne strukture međunarodnih odnosa oličene u rivalstvu dve najveće sile tog vremena - Sjedinjenih Američkih Država i Sovjetskog Saveza - prisustvovali smo do tada nezabeleženom uzletu i globalnoj dominaciji prvonavedene države kao jedine posthladnoratovske supersile, koja je stvorila unipolarnu strukturu. Prema stavovima mnogih teoretičara, od kojih se izdvajaju Francis Fukuyama i Eric Hobsbawm, kraj Hladnog rata označio je "kraj istorije" zbog ideološkog trijumfa i privlačnosti ideja koje sadrži koncept liberalne demokratije, dok smo padom Berlinskog zida izašli iz kratkog i nemirnog dvadesetog veka koji je trajao od Prvog svetskog rata (1914-1918) do 1989/1990. godine, čime je istorija dvadesetovekovnog "doba ekstrema" uplovila u mirne vode (Fukuyama, 1989; Hobsbaum, 2004). Međutim, unipolarni momenat koji je stvorio međunarodni liberalni poredak dobio je nužno, kao i svaki globalni poredak tokom istorije na svojim vrhuncima, svoju dijalektičku antitezu, shodno tezi o dinamičkom ustrojstvu svetske istorije koja je izložena u nizu filozofija istorije od Hegela preko Marxa sve do niza mislilaca XX veka poput Henryja Kissingera, a shodno kojima je svaka etablirana istorijska realizacija određenog svetskog istorijskog poretka istovremeni početak njegove dekompozicije. ${ }^{1}$ Aktuelna antiteza međunarodnom liberalnom poretku predvođenom Sjedinjenim Američkim Državama i njegovoj unipolarnosti je u narastajućoj moći neliberalnih svetskih sila poput Rusije i Kine, kao i u pojavi transnacionalnih i nedržavnih aktera te, konačno, u nizu događaja i kriza koje potkopavaju temelje na kojima je svetski liberalni poredak stvaran, bez obzira na to da li je reč o nestabilnostima unutar samih liberalnih društava čiji smo svedoci proteklih godina ili o širim geopolitičkim procesima koji slabe snagu globalnog liberalnog poretka i sužavaju njegov manevarski prostor. Povratak u geopolitičku igru pomenutih aktera, kao i uopšte "povratak geopolitike" kome svedočimo poslednjih godina, pokazuje da "muze istorije" nikada ne miruju i da politički još uvek zapravo živimo u "dugom dvadesetom veku" koji odlikuju napetosti karakteristične ne samo za ovaj burni vek, već i uopšte za čitavu političku Modernu, od njenih samih početaka nakon Vestfalskog mira 1648. godine i uspostavljanja modernog međunarodnog sistema država, koji je otada u stalnom pulsiranju i prekomponovanju (Cvetićanin, 2017a).

Rad se, pored uvoda i zaključka, sastoji od tri poglavlja. U prvom poglavlju opisujemo i dajemo pregled uspona moći SAD nakon Hladnog rata i urušavanja bi-

${ }^{1}$ I pored očiglednih razlika u Hegelovoj, Marxovoj i Kissingerovoj filozofiji istorije (Hegel, 1966; Marks, 1964; Kissinger, 1994) uslovljenih različitošću vremena i ideologija koje su zastupali ovi autori (Hegel pruski konzervativizam, Marx revolucionarni komunizam, Kissinger tzv. Realpolitik), zajednička osobina ovih triju filozofija istorije je što su svaka na svoj način udaljene od liberalnog normativizma kome spore univerzalnost, doživljavajući ga tek kao jedan istorijski pol, odnosno tek kao jednu "istorijsku snagu" među drugim istorijskim snagama, koje su sve zajedno u stalnoj napetosti i borbi svojih interesa. 
polarne strukture međunarodnog sistema i prelaska na unipolarnost, kao i stvaranje novog svetskog poretka utemeljenog na ideologiji globalnog liberalizma koja u sebi sadrži osnovne postavke teorija liberalnog mira, demokratskog mira i neoliberalnog institucionalizma. Drugi deo rada posvećen je deskripciji procesa urušavanja globalnog liberalnog poretka i postepenog jačanja drugih globalnih aktera, što rezultira prekomponovanjem globalne strukture međunarodnih odnosa i povratkom geopolitičkog revizionizma i ideoloških previranja širom sveta. Treći deo rada posvećen je takozvanoj dijalektici političke mehanike koja služi kao analitička alatka kojom nastojimo da objasnimo aktuelne promene u međunarodnim odnosima i ulazak u predvorje jednog novog, postliberalnog, multipolarnog, svetskog poretka.

\section{Uspon moći SAD i stvaranje liberalnog međunarodnog poretka}

Unipolarni momenat nastao nakon okončanja Hladnog rata i urušavanja bipolarne međunarodne strukture predstavlja redak momenat u istoriji svetske politike. Bivši ministar spoljnih poslova Francuske Hubert Védrine dao je 1999. godine izjavu u kojoj SAD nije definisao samo kao jedinu svetsku supersilu, smatrajući takvu kovanicu anahronizmom hladnoratovske ere, već je SAD označio kao hipersilu (hyperpower) zbog moći koja ne obuhvata samo vojnu, ekonomsku i tehnološku dominaciju nad ostatkom sveta, već uključuje i moć da se dominantno utiče na svakodnevni život širom sveta i da se određuju njegovi modaliteti (To Paris..., 1999).

Ovakav uzlet američke moći u neposrednom periodu nakon pada Berlinskog zida stvorio je euforiju širom zapadnog sveta o konačnom trijumfu modela liberalne demokratije i slobodnog tržišta te o stvaranju novog svetskog poretka pod okriljem SAD kao "dobroćudnog" hegemona. Nagli kolaps i raspad Sovjetskog Saveza ostavio je SAD kao dominirajuću silu u međunarodnom sistemu. Nakon raspada parirajuće supersile nastupa unipolarni momenat koji predstavlja jedinstvenu istorijsku epizodu od kada je uspostavljen moderni Vestfalski sistem. ${ }^{2}$ Prema Stewartu Patricku unipolarni svet na čelu sa SAD predstavlja presedan iz dva razloga. Prvi razlog je taj što novi poredak nije nastao kao posledica prekomponovanja međunarodnog sistema nakon velikog svetskog rata kao što je to bio slučaj 1815, 1919. ili 1945. godine, već kroz miran raspad jednog od vodećih aktera u sistemu. Drugi razlog jeste što novih izazivača američkoj moći u tom trenutku nije bilo ni na horizontu (Patrick, 2013: 17). Ovakav momenat u istoriji označio je da uticaj SAD ima globalni domašaj i da su one u stanju da projektuju svoju vojnu, političku i ekonomsku moć širom planete. Nepostojanje takmaca američkoj moći i dominaciji dovelo je u pitanje klasične postavke teorije strukturalnog realizma o formiranju kontrahegemon-

2 Kovanicu "unipolarni momenat" prvi put je upotrebio Charles Krauthammer u časopisu Foreign Affairs kako bi opisao narastajuću moć SAD. Videti više u: Krauthammer, 1990. 
ske koalicije bilo u formi tvrdog ili mekog balansiranja. ${ }^{3}$ Kenneth Waltz, jedan od najistaknutijih teoretičara strukturalnog realizma, takođe smatra da narušena ravnoteža mora biti ponovo uspostavljena, sa ogradom da se to ne mora desiti odmah. Strukturalni realizam jeste teorija koja objašnjava međunarodne ishode i način na koji struktura međunarodnog sistema pritiska države, ali nije teorija koja će objasniti kako će pojedinačne države nužno odgovoriti na spoljne okolnosti (Waltz, 2000). Međutim, države su kao strategiju opstanka iskoristile još jednu postavku koja jeste deo korpusa realističke teorije - svrstavanje uz jačega (bandwagoning). Nemogućnost kontrahegemonističkog balansiranja je po Williamu Wohlforthu ležala u dominantnoj relativnoj nadmoći koje su SAD uživale nad potencijalnim takmacima kao što su Rusija, Evropa, Japan i Kina. Rusija je kao sukcesor Sovjetskog Saveza bila zaokupljena unutrašnjim problemima, Evropa je na stolu imala ujedinjenje Nemačke i prekomponovanje i produbljivanje evropskih integracija, Japan je stao sa ekonomskim rastom, a Kina je tek započinjala svoj uspon (Wohlforth, 1999).

Upravo je strategija opstanka oličena u svrstavanju uz SAD omogućila stvaranje liberalnog međunarodnog poretka pod okriljem SAD. Za razliku od Johna Ikenberrya, stav autora ovog rada je da liberalni međunarodni poredak svoj uzlet doživljava paralelno sa pojavom unipolarne strukture međunarodnog sistema. Ikenberry je, nasuprot tome, zastupnik teze da je liberalni međunarodni poredak nastao nakon okončanja Drugog svetskog rata (Ikenberry, 2018). Međutim, iako ne negiramo postojanje liberalnog poretka tokom Hladnog rata, smatramo da on nije bio međunarodni po svom domašaju. Rivalstvo dve supersile hladnoratovskog vremena kreiralo je dva međusobno suprotstavljena poretka, jedan liberalni i drugi socijalistički, između kojih je vladala bezbednosna napetost i nedostatak međusobne saradnje. Upravo su raspad potonjeg bloka i spuštanje "Gvozdene zavese" sa svetske pozornice omogućili da pobednički blok svoj poredak pokuša da učini globalnim.

Uspon i stvaranje nove ere međunarodnih odnosa obelodanio je 1990. godine tadašnji predsednik SAD George H. W. Bush najavljujući do tada neviđeni period saradnje između nacija i stvaranje "novog svetskog poretka". Po njegovim rečima takvo doba bi bilo "oslobođeno straha od terora, snažnije u potrazi za pravdom, sigurnije u mir" i to bi bila "era u kojoj će sve države sveta, bez obzira na to nalaze li se na Zapadu ili Istoku, Severu ili Jugu, prosperirati i živeti u harmoniji” (Bush, 1990). Bill Clinton, Bushov naslednik na mestu predsednika SAD, samo je dodatno osnažio viziju svog prethodnika. David Hendrickson primećuje da je Clinton, uprkos kritikama upućenim tadašnjem predsedniku Bushu da je zbog spoljne politike zapostavio unutardržavne probleme, imao faktički mnogo ambiciozniju spoljnopolitičku agendu nego njegov prethodnik. Isti autor tvrdi da je Bushova ideja svetskog

3 Videti više u: Mearsheimer, 1990. 
poretka bila fokusirana na ideju kolektivne bezbednosti koja bi podrazumevala da Ujedinjene nacije sa podrškom SAD garantuju teritorijalni integritet i političku nezavisnost svih članova međunarodnog društva (Hendrickson, 1994: 26-27). Međutim, spoljna politika predsednika Clintona bila je bazirana na sveukupnoj liberalnoj agendi i ideji koja je u sebe inkorporirala ideje liberalnog mira, demokratskog mira i neoliberalnog institucionalizma.

Prvi stub u okviru pomenute liberalne agende i ideje jeste liberalni mir, odnosno teorija liberalnog mira koja je nastala u XVIII veku kao reakcija na merkantilističke trgovačke politike i ukazuje na značaj ekonomskih sloboda i trgovine, a jedan od prvih autora koji je objasnio uticaj slobodne trgovine na izgradnju mira jeste Adam Smith u svom delu Bogatstvo naroda objavljenom 1776. godine (Smith, 1952, citirano u Ejdus, 2012: 81). Prema Smithu "nevidljiva ruka" slobodnog tržišta, osim što uvećava bogatstvo naroda, istovremeno smanjuje mogućnost njihovog međusobnog sukoba. Thomas Friedman na slikovit način, pod uticajem pomenute teorije liberalnog mira i društvene teorije mekdonaldizacije Georgea Ritzera, objašnjava da se narodi koji imaju McDonald's restorane ne sukobljavaju međusobno, već više vole da mirno u redovima čekaju svoje hamburgere (Friedman, 2000: 249, citirano u Ejdus, 2012: 82).

Teorija demokratskog mira predstavlja drugi stub u korpusu liberalne teorije. Centralni fokus ove teorije jeste teza da je ključ za očuvanje mira postojanje demokratije. Teorija demokratskog mira ima dugu tradiciju s obzirom na to da se njeno poreklo vezuje za čuvenog filozofa klasičnog nemačkog idealizma Immanuela Kanta iz XVIII veka i za njegovo delo Večni mir. Kantovo učenje predstavlja monadičnu teoriju demokratskog mira, zbog glavne teze da su demokratije manje ratoborne nego države sa nedemokratskim uređenjem vlasti. Međutim, vremenom je monadična teorija ustupila mesto dijadičnoj teoriji demokratskog mira koja u fokus stavlja rešavanje sukoba isključivo između država koje karakteriše demokratski oblik vlasti. To znači da je napuštena prvobitna teza da su demokratije manje ratoborne od nedemokratija i zamenjena tezom da demokratije ne vode međusobne ratove. Jedan od savremenih autora za koje se najviše vezuje pomenuta teorija jeste Michael Doyle, koji je ovakvu ideju lansirao u članku Kant, liberal agencies and foreign affairs (Doyle, 1983). ${ }^{4}$ Autori John O’Neal i Bruce Russett sproveli su kvantitativno empirijsko istraživanje u kojem je obuhvaćen hladnoratovski period od 1950. do 1985. godine kako bi dokazali dijadičnu teoriju demokratskog mira i došli do zaključka da je malo verovatno da će se demokratije upustiti u međusobni sukob, dok isti slučaj ne važi za međusobni odnos između demokratija i autokratija (O’Neal i Russett, 1997). John Mearsheimer (2017: 45) primećuje da postoji mno-

${ }^{4}$ O teoriji demokratskog mira pogledati još: Doyle, 1986. 
štvo objašnjenja za mir među demokratijama, ali malo saglasnosti o pravom razlogu ove pojave. ${ }^{5}$

Treći stub u okviru korpusa liberalne teorije jeste teorija neoliberalnog institucionalizma. Za razliku od teorija liberalnog i demokratskog mira koje više ističu značaj projekcije unutardržavnih faktora u međunarodnu arenu, neoliberalni institucionalisti ističu značaj postojanja međunarodnih institucija koje regulišu odnose između država. Iako dele neorealističku pretpostavku da je međunarodni sistem anarhičan zbog nepostojanja jedinstvenog vrhovnog autoriteta nad suverenim državama, neoliberalni institucionalisti smatraju da međunarodne ustanove podstiču saradnju među državama i tako umanjuju šansu za njihovo međusobno sukobljavanje i nadmetanje. ${ }^{6}$ Glavna vododelnica između realističkog i liberalnog viđenja međunarodnih institucija jeste odnos između apsolutnih i relativnih dobitaka. Za realiste međunarodne institucije predstavljaju pre svega instrument moći najjačih država $u$ međunarodnom sistemu, te su one isključivo zainteresovane za relativne dobitke. Sa druge strane, liberalni teoretičari smatraju da međunarodne institucije nisu instrument u rukama najmoćnijih država, već postoje kako bi se zaštitili interesi svih

5 Jednu od istaknutijih grupa u objašnjavanju ove pojave možemo nazvati institucionalnom zbog toga što naglašava značaj postojanja demokratskih ustanova unutar države. Po ovom shvatanju postojanje podele vlasti, tj. sistema checks and balances otežava donošenje odluke o pokretanju rata. Takođe, zbog postojanja koalicionih vlada smatra se da bi pokretanje nepopularnog, nepotrebnog ili gubitničkog rata dovelo do pada podrške vladajućim strukturama u javnom mnjenju i u eventualnom izbornom procesu. Javnost postupka u demokratijama takođe ublažuje bezbednosnu dilemu zbog nemogućnosti naglog napada i samim time podstiče bezbednosnu saradnju. Drugo krilo predstavljuju normativisti koji zastupaju tezu da demokratije norme unutrašnjeg rešavanja sporova primenjuju u međunarodnim odnosima (Ejdus, 2012: 83-84).

${ }^{6} \mathrm{U}$ okviru korpusa teorija neoliberalnog institucionalizma izdvajaju se tri različite grupe mišljenja. U prvu grupu spadaju liberalni institucionalisti koji, za razliku od realista, smatraju da je saradnja između država pod okriljem međunarodnih ustanova izvesnija nego što potonji smatraju, pogotovo u vezi sa ekonomskim i ekološkim pitanjima. Međunarodne ustanove i pravila koja ih tvore i koja obavezuju države članice određene organizacije smanjuju verovatnoću da jedna od njih može da prevari ostale, što predstavlja glavnu prepreku sukobu između država. U drugu grupu spadaju teoretičari koji ističu značaj institucija kolektivne bezbednosti. Teoretičari kolektivne bezbednosti fokusirani su na pobijanje realističkih pretpostavki o sebičnim akterima u međunarodnom sistemu koji u cilju promene statusa quo uvek mogu pribeći upotrebi sile, i stavljaju akcenat na to da institucije kolektivne bezbednosti služe stvaranju uslova gde nijedna država ne može imati maksimalističke tendencije usled toga što je ostale države unutar institucija odvraćaju od upotrebe sile. Treća grupa jesu kritički teoretičari. Cilj kritičkih teoretičara nije ograničen samo na povećanu saradnju među državama, već je potpuna transformacija svetske politike koja bi omogućila postojanje večnog mira. Kritički teoretičari smatraju da materijalna struktura međunarodnog sistema po sebi ne postoji, već da je ona produkt ideja i diskursa. O nabrojane tri teorije neoliberalnog institucionalizma i odgovoru iz perspektive neoklasičnog realizma videti više u: Mearsheimer, 1994. 
država koje sarađuju. Po njima, države su motivisane apsolutnim dobicima i saradnja u okviru institucija smanjuje bezbednosnu dilemu koja postoji te predstavlja forum za mirno rešavanje sporova. Liberalni teoretičari oslanjaju se na tezu Roberta Keohanea i Josepha Nyea da svet ne pripada samo državama i da u svojoj suštini postaje transnacionalan zbog usložnjenih veza između države, tržišta i pojedinačnih aktera. U usložnjenom svetu sa mnoštvom transnacionalnih veza sukobi su manje verovatni, a nacionalni interesi ustupaju mesto globalnim (Keohane i Nye, 1977, citirano u Ejdus, 2012: 87-88).

Liberalne ideje bile su inkorporirane i u Strategiju nacionalne bezbednosti SAD iz 1994. godine koju je donela administracija predsednika Clintona pod nazivom A National Security Strategy of Engagement and Enlargement. ${ }^{7}$ Strategija je predvidela dodatno jačanje odnosa sa hladnoratovskim saveznicima i dublju integraciju, i sa njima i sa ostatkom sveta, u sve širu koaliciju država sa slobodnim tržištem i demokratskim uređenjem. Vladajuće strukture u SAD ušle su u pohod stvaranja novog svetskog poretka sa idejom da u njega budu inkorporirane i sile koje tokom hladnoratovskog perioda nisu bile njeni saveznici, a tu se najpre misli na Rusiju i Kinu. John Mearsheimer smatra da su SAD na taj način nastojale da prevaziđu koncepte strukturalnog realizma kao što su ravnoteža snaga i bezbednosna dilema te da od Rusije i Kine, potencijalno dva najveća takmaca, naprave tržišno orijentisane zemlje u potpunosti uključene u svetsku ekonomiju, ali i države sa liberalno-demokratskim uređenjem (Mearsheimer, 2019: 23). Koristeći terminologiju istaknutog teoretičara međunarodnih odnosa Arnolda Wolfersa, SAD su se upustile, s obzirom na uspostavljenu globalnu dominaciju i nepostojanje dostojnog takmaca, u ambiciozno kreiranje "spoljnog miljea" (Wolfers, 1962: 73-75). Devedesete godine XX veka SAD su na spoljnom planu najviše posvetile širenju i konsolidaciji vodećih multilateralnih foruma, međunarodnih i regionalnih organizacija te jačanju postojećih saveza. Međunarodne institucije koje su do tada funkcionisale bile su deo "ograničenog zapadnog poretka" i nisu imale globalni domašaj. Retke organizacije, kao Ujedinjene nacije, predstavljale su forum u koji su bile uključene sve sile tokom hladnoratovskog perioda, ali je međuzavisnost između njih bila izuzetno niska, što je formiralo samo "tanki" međunarodni poredak (Mearsheimer, 2019: 1516). SAD su naspram "tankog" međunarodnog poretka nastojale da u "puni" međunarodni poredak uključe što više aktera, po mogućstvu sve.

Integrisanje Rusije i Kine u globalne ekonomske i finansijske tokove bilo je relativno uspešno. Rusija je postala članica Međunarodnog monetarnog fonda (MMF) i Svetske banke 1992. godine, relativno brzo nakon pada Berlinskog zida. Doduše, članica Svetske trgovinske organizacije (STO) Rusija postaje tek 2012. go-

7 Videti više u: White House, 1994. 
dine. ${ }^{8}$ Kina je članica MMF i Svetske banke postala još tokom hladnoratovskog perioda, a STO je pristupila 2001. godine. Period devedesetih godina u trouglu SAD - Rusija - Kina prošao je bez većih napetosti, što je dalo signal političkim elitama u SAD da sprovođenje liberalne spoljnopolitičke agende daje rezultate.

Paralelno sa razvojem odnosa $u$ pomenutom trouglu stari hladnoratovski saveznici na tlu Evrope ušli su u sasvim novu etapu integracija. Padom Gvozdene zavese i izlaskom zemalja Istočne Evrope iz socijalističkog lagera stvoreni su uslovi za reunifikaciju Nemačke i "povratak" ostalih zemalja u političku arhitekturu starog kontinenta. Pored uslova za proširenje i stvaranje novog panevropskog projekta Evropa je bila na putu produbljivanja postojećih integracija. U tom duhu 1992. godine potpisan je Ugovor o Evropskoj uniji u Maastrichtu, poznatiji i kao Mastriški ugovor, koji je dotadašnje Evropske zajednice koje su bile prevashodno ekonomskog karaktera transformisao u novi politički entitet - Evropsku uniju (EU). EU je po Mastriškom ugovoru počivala na tri stuba. Prvi stub obuhvatao je prethodno postojeće Evropske zajednice (Evropska zajednica za ugalj i čelik, Evropska ekonomska zajednica i Evropska zajednica za atomsku energiju); drugi stub činio je sistem Zajedničke spoljne i bezbednosne politike; treći stub obuhvatao je sferu koja se odnosila na pravosuđe i unutrašnje politike. ${ }^{9}$ Još jedan značajan pomak i indikator produbljivanja evropske integracije i njenog ulaska u "zlatno doba" predstavljalo je uvođenje eura kao valute 1999. godine.

U ovom periodu dve međunarodne institucije, pomenuta EU i NATO, ostvaruju svoj plan o proširenju na zemlje Centralne i Istočne Evrope. Mearsheimer napominje da se strategije širenja ove dve organizacije ne mogu razmatrati odvojeno, već da potpadaju pod isti korpus agende vođenja liberalne spoljne politike zemalja Zapada. Pomeranje Zapada prema Istoku prati realističku logiku obuzdavanja potencijalno agresivne Rusije. Međutim, proširenje EU i NATO nije imalo za cilj puko geostrateško teritorijalno širenje, već stvaranje zajednice liberalnih vrednosti te stvaranje nove evropske političke i bezbednosne arhitekture (Mearsheimer, 2019: 23). Politika proširenja EU po prvi put je formalizovana 1993. godine na samitu u Kopenhagenu kada su uvedeni jasni kriterijumi za stupanje u članstvo novih država zbog njihovog "nezapadnog" institucionalnog nasleđa. Ti kriterijumi bili su u skladu sa vođenjem liberalne spoljne politike tadašnjih evroatlantskih saveznika i obuhvataju: 1) stabilnost institucija koje garantuju demokratiju, vladavinu prava,

${ }^{8}$ Transformacija Opšteg sporazuma o carinama i trgovini (GATT) u STO 1995. godine predstavlja vid političkog podsticanja rasta svetske trgovine i njenu institucionalizaciju u okviru pomenute organizacije. Stvaranje STO uklapa se u stvaranje međunarodnih institucija i razvoja svetske trgovine u skladu sa spoljnopolitičkom agendom SAD u tom periodu. Više o značaju i funkcionisanju STO videti u: Oatley, 2015.

9 O razvoju evropskih integracija i sektorskim politikama videti više u: Dinan, 2009; 2010. 
zaštitu ljudskih i manjinskih prava; 2) postojanje tržišne privrede; 3) prihvatanje tekovina acquis communautaire.$^{10} \mathrm{U}$ širenju prema Istoku EU je uspešno sprovodila politiku uslovljavanja, mehanizam koji je omogućio ubrzanu demokratizaciju ovih zemalja i prihvatanje pravnih i političkih tekovina EU, što je rezultiralo velikim proširenjem 2004. godine (Schimmelfennig i Sedelmeier, 2004). ${ }^{11}$

\section{Pukotine u liberalnom poretku i povratak geopolitičkih napetosti}

U drugim krajevima sveta stvaranje liberalnog poretka bio je ambiciozniji i neizvesniji poduhvat u odnosu na rezultate u Evropi, ali ne i bez uspeha. Potpisan je sporazum u Oslu između Izraela i PLO, SAD podržane od Saveta bezbednosti UN uspele su da pobede Irak u Zalivskom ratu i oslobode Kuvajt, a broj demokratija u svetu se tokom ovog perioda znatno uvećao (Mearsheimer, 2019: 26-27). Međutim, već početkom novog milenijuma pojavljuju se osetne pukotine u liberalnom poretku koje dovode u pitanje njegovu održivost. Dolaskom predsednika Georgea W. Busha i njegove administracije u Belu kuću 2001. godine ispoljavaju se tendencije prema unilateralnom kreiranju i sprovođenju spoljnopolitičke agende naspram dominirajućeg multilateralizma u prethodnom periodu. No, to nije označilo ni pad američke moći u svetu i kraj njenog unipolarizma ni odustajanje od principa liberalne spoljne politike. Administracija predsednika Georgea W. Busha gajila je duboko nepoverenje u postojeće međunarodne institucije i njihov kapacitet da se izbore sa nadolazećim izazovima, rizicima i pretnjama po nacionalnu i svetsku bezbednost. Teroristički napadi 11.9. 2001. godine su pokazali da je foedus pacificum još uvek daleko od ostvarenja. Sve veća opasnost od netradicionalnih aktera međunarodnih odnosa podstakla je SAD da usvoje novu strategiju nacionalne bezbednosti baziranu na doktrini preventivnog rata, što je rezultiralo u radikalnoj ambiciji da se što brže nametne liberalna agenda u delovima sveta gde je to smatrano neophodnim kako bi se učvrstila američka moć i dominacija. Pomenuti teroristički napadi podstakli su Bushovu administraciju da proglasi globalni rat protiv terora uz manihejsku konstataciju da su ostale države u toj borbi sa njima ili protiv njih (Patrick, 2013: 21). Bushova administracija je, svesna moći koju SAD poseduju u međunarodnom sistemu, nastojala da bude garant očuvanja postojećeg poretka i predvodnik demokratske re-

10 Videti više u: European Council, 1993.

11 Zemlje koje su 2004. godine dobile status države članice EU su Slovenija, Mađarska, Češka, Slovačka, Poljska, Litvanija, Letonija, Estonija, Malta i Kipar. Bugarska i Rumunija stekle su punopravno članstvo 2007. godine, a Hrvatska je pristupila 2013. godine. Mađarska, Češka i Slovačka postale su članice NATO 1999. godine. Tokom 2004. godine, u istoj godini kad je EU primila najveći broj država članica, članice NATO postaju Bugarska, Rumunija, Slovačka, Slovenija, Estonija, Litvanija i Letonija. Hrvatska i Albanija pristupaju 2009. godine, Crna Gora 2017. godine, a poslednja članica saveza postala je Severna Makedonija 2020. godine. 
volucije širom sveta. Bushova velika strategija u spoljnoj politici bila je, po rečima Stewarta Patricka, vilsonizam bez međunarodnih institucija (ibid.).

Intervencija i započinjanje rata u Iraku 2003. godine poljuljali su poverenje $\mathrm{u}$ globalno liderstvo SAD s obzirom na to da je akcija pokrenuta uz protivljenje evropskih saveznika - Francuske i Nemačke. Ubrzo je postalo jasno da intervencija u Iraku predstavlja potpunu katastrofu spoljne politike SAD uzimajući u obzir dužinu rata i neuspeh transformacije političkog sistema u Bagdadu u liberalno-demokratski oblik vladavine. Možda još očitiji primer neuspeha spoljnopolitičke agende bazirane na promociji demokratskih vrednosti predstavlja rat u Avganistanu, s obzirom na to da je najduži oružani sukob u istoriji SAD. Ovakvi potezi SAD u globalnoj areni stvorili su sumnju mnogih svetskih aktera u benignost američke hegemonije. Izbor i dolazak Baracka Obame na mesto predsednika SAD teško je mogao da popravi pokrenuti ireverzibilni proces pada liberalnog svetskog poretka, uprkos najavama predsednika Obame da SAD ulaze u "novu eru angažovanja" oličenu u pojačanoj multilateralnoj saradnji, kolektivnom upravljanju globalnim krizama, mirnoj integraciji nadolazećih svetskih i regionalnih sila u međunarodni poredak te modernizaciji i obnavljanju poverenja u međunarodne ustanove. Međutim, ovakva spoljnopolitička strategija nije doprinela održanju pređašnjeg stepena moći liberalnog međunarodnog poretka, već, upravo suprotno, njegovoj eroziji.

Prve dve decenije XXI veka su, nasuprot očekivanjima, pokazale svu složenost svetskih odnosa. Ambiciozni projekat stvaranja mirnog sveta baziranog na univerzalističkim vrednostima liberalne demokratije nije uspeo da spreči nadolazeće krize. Tokom ovog perioda došlo je do globalne finansijske krize 2008. godine koja je poljuljala poverenje u principe liberalne ekonomije, a tu su bile i druge krize koje su najavljivale "povratak geopolitike": povećane regionalne nestabilnosti na Bliskom istoku, obnovljen sukob Izraela i Palestine, Arapsko proleće 2011. godine i neuspešno formiranje funkcionalne države u Libiji, rat u Siriji 2014. godine, početak priliva talasa migranata u Evropu, rat u Ukrajini 2014. godine i posledično zahlađenje odnosa između Zapada i Rusije, rast neliberalnih tendencija u liberalnom svetu, izlazak Ujedinjenog Kraljevstva iz EU 2016. godine, uspon Kine i njeno dovođenje u pitanje do tada neupitne moći SAD te, konačno, izbor Donalda Trumpa 2016. godine za predsednika SAD, kao prvog predsednika koji se otvoreno protivio dotadašnjoj američkoj globalnoj liberalnoj paradigmi. Hal Brands i Eric Edelman smatraju da je najbolji način razumevanja postojeće ere poređenje sa prethodnom. Pomenuti autori smatraju da postoje evidentne razlike koje ukazuju na to da se svet u poslednje tri decenije transformisao. Kao prvu ključnu strukturalnu promenu u međunarodnom sistemu ističu eroziju i opadanje svetske dominacije SAD i celokupnog zapadnog sveta. SAD i dalje jesu vodeća svetska sila, ali danas je njihov primat u svetu ugrožen kao nikada u posthladnoratovskom periodu. SAD i dalje 
predstavljaju najjaču ekonomiju po nominalnom BDP te isto tako poseduju najizraženiju "tvrdu moć" oličenu u mogućnosti projektovanja vojne sile širom sveta zbog posedovanja impresivnog oružanog arsenala. ${ }^{12}$ Međutim, udeo SAD u svetskom bogatstvu opada. Po podacima do kojih dolaze pomenuti autori, udeo SAD u svetskom bogatstvu i troškovima za vojne svrhe opao je sa $25 \%$ i $42 \%$ tokom 2004. godine na 22\% i 34\% u 2015. godini (Brands i Edelman, 2017). Takođe, pad $\mathrm{u}$ istom udelu tokom ovog perioda osetili su i saveznici SAD na evropskom i azijskom kontinentu. SAD i dalje jesu najmoćnija sila u svetu, ali ovakve promene i dovođenje u pitanje doskora neprikosnovene uloge SAD u svetskom sistemu omogućavaju takmacima da učestvuju u preoblikovanju međunarodnog poretka u skladu sa svojim preferencijama. Ovakve strukturalne promene dovode do druge glavne odlike savremenog doba - povratka geopolitičkog revizionizma i rivalstva velikih sila. Opozitne velike sile su iskoristile sopstveni uspon u relativnoj raspodeli moći u globalnoj areni da dovedu u pitanje liberalni poredak u nekoliko geopolitičkih žarišta u svetu. Regioni poput Istočne Azije, Bliskog istoka i Istočne Evrope postaju geopolitički plen različitih sila koje se bore da stvore što veći uticaj u područjima koja su im strateški bitna. Uvećanje kineske moći podstaklo je zvanični Peking da u regionu Istočne Azije umanji uticaj SAD i da krene u formiranje regionalnog poretka koncentrisanog oko Kine. Geopolitičko rivalstvo u regionu Bliskog istoka, područja sa tradicijom dugotrajnih i kompleksnih konflikata, sa snaženjem pojedinih regionalnih aktera poput Irana i Saudijske Arabije, ukazuje na to da se na tom prostoru održivi mir još ne nazire na horizontu. Ukrajinska kriza pokazala je i da Evropa nije otišla u zatišje istorije. Rusija je dolaskom Vladimira Putina i njegove ere vladavine u Kremlju strpljivo čekala stvaranje povoljnog geopolitičkog miljea kako bi demonstrirala svoj potencijal i ulogu izrazito važnog globalnog aktera. Učešće Rusije u ratu u Ukrajini raspršilo je snove o slobodnoj i mirnoj posthladnoratovskoj Evropi. Takođe, učešće Rusije u ratu u Siriji pokazalo je svetskoj javnosti da Rusija ima sposobnost da projektuje svoju političku i vojnu moć i izvan granica postsovjetskog prostora i neposrednog susedstva (ibid.). Uz ogradu da svaki region poseduje sopstvene posebnosti i da tenzije i sukobi u različitim geopolitičkim regionima nisu istovetni, ipak oslikavaju jedan proces i dinamičan talas savremenih međunarodnih tokova. Treća karakteristika trenutne ere jeste dovođenje u pitanje ideološkog liberalnog političkog i ekonomskog narativa na čijim temeljima je građena ideja međunarodnog liberalnog poretka. Ideološki revizionizam došao je u svetske tokove "ruku pod ruku" sa geopolitičkim. Po rečima

12 Podaci o nominalnom BDP za 2019. godinu dostupni su na: https://data.worldbank.org/indicator/NY.GDP.MKTP.CD?most_recent_value_desc=true (pristupljeno 25. 11. 2020); podaci o vojnim troškovima država dostupni su na: https://www.statista.com/statistics/262742/countrieswith-the-highest-military-spending/ (pristupljeno 25. 11. 2020). 
Hala Brandsa ideologije predstavljaju "pogonsko gorivo" geopolitičkog rivalstva (Brands, 2018: 62):

Glavni branilac postojećeg međunarodnog poretka je liberalna demokratija koja je tradicionalno nastojala da globalno okruženje oblikuje u skladu sa svojim ideološkim vrednostima i svojim strateškim interesima. Vodeći revizionisti su autokratije koje praktikuju izrazito autoritarnu verziju kapitalizma i vide napredovanje liberalnih ideala kao egzistencijalnu pretnju njihovom legitimitetu i moći. Ovi različiti pristupi upravljanju i društvu nikada nisu daleko od površine u svetskoj politici. Možda nismo svedoci novog Hladnog rata u kome se dve dijametralno suprotne i univerzalističke ideologije prepliću u konkurenciji i propagiraju se širom sveta. Ali nije slučajno što se današnji najoštriji geopolitički sukobi vode po ideološkim linijama.

Osim što velike sile poput Rusije i Kine nisu prihvatile ideje i temelje na kojima počiva liberalna demokratija i inkorporirale ih u sopstveni politički sistem, to nisu uradile ni značajne regionalne sile poput Turske i Irana. Međutim, liberalni poredak nije doveden u pitanje samo spolja, već i iznutra. Projekat proširenja EU na države Centralne i Istočne Evrope iz ove perspektive ukazuje na to da je ovakav nadnacionalni projekat bez presedana "pojeo više nego što može da svari”. Poljska i Mađarska, po stavovima mnogih teoretičara, gotovo da postaju neliberalne demokratije. U Poljskoj je političku klimu uzburkalo donošenje novog zakona o abortusima koji se sukobljava sa osnovnim proklamovanim evropskim i liberalnim vrednostima (Poland delays..., 2020). Mađarska, po rečima Jamesa Kirchicka, jeste "demokratija bez demokrata" u samom središtu evropskog kontinenta (Kirchick, 2017: 40-71). Viktor Orban, dugogodišnji premijer Mađarske, izjavio je da je era liberalne demokratije gotova (Viktor Orban..., 2018). Najveći udarac liberalnom poretku iznutra svakako je predstavljao BREXIT - izlazak Ujedinjenog Kraljevstva iz EU. Ovakvi potezi pomenutih zemalja pokazuju želju vladajućih elita da povrate onoliko suvereniteta koliko im okolnosti dozvoljavaju - Ujedinjeno Kraljevstvo vratilo je sebi pun suverenitet, dok ostale države nastoje da egzistiraju između povratka državnog suvereniteta i ostataka širih institucionalnih integracija (Cvetićanin, 2016). Liberalni poredak je pretrpeo specifičan udarac i izborom Donalda Trumpa za predsednika SAD. Predsednik Trump je više puta izražavao prezir prema međunarodnim institucijama koje su činile osnov liberalnog sveta, kao što su EU i NATO, što je izazvalo krizu transatlantskog partnerstva. Dolazak Trumpa na mesto predsednika desio se upravo na krilima nepoverenja velikog dela javnog mnjenja u SAD prema političkim elitama koje su kreatori liberalnog međunarodnog poretka. Bez obzira na Trumpovo lično nepoverenje prema međunarodnim ustanovama i raznim oblicima međunarodne multilateralne saradnje, rivalitet između velikih sila i koncepcija kako svet treba da izgleda ipak nije samo borba između pojedinačnih 
lidera, već je njegova pojava uvek uslovljena dubljim strukturalnim dešavanjima, gde su pojedine političke ličnosti poput Trumpa zapravo posledica, a ne uzrok dubljih promena globalnog političkog polja. Kakva god da bude politička budućnost Donalda Trumpa, njegovu samu pojavu u "svetskoj istoriji" možemo tumačiti slabljenjem globalne liberalne paradigme. Konačno, slažemo se sa Brandsom da tenzije i rivalstvo između većih sistema nisu ukorenjeni u sukobu ličnosti, već pre svega u sasvim različitim viđenjima političkog i geopolitike (Brands, 2018: 63).

\section{Dijalektika političke mehanike i povratak Vestfalskog suvereniteta}

Naivno bi bilo pomisliti da se promene u međunarodnom sistemu i u odnosima između država dešavaju niotkuda i da nastaju u vakuumu. Istorija posle pada Berlinskog zida i širenja liberalnog poretka širom sveta nije postala manje raznolika nego što je bila pre. Uspon i "pad" liberalnog sveta i njegov postepeni prelazak u doba rivalstva velikih sila i sve učestalijeg otpora vrednostima liberalnog političkog modela moguće je objasniti analitičkim oruđem kojim se jedan od autora ovog rada koristio u prethodnim istraživanjima. Koncept dijalektike političke mehanike, koji može objasniti prethodno navedene promene i potrese unutar liberalnog poretka, nije analitički koncept ex nihilo, nego zapravo predstavlja modifikovanu dijalektičku metodu. Svođenje osnovnih postavki modernog "oca osnivača" pomenute metode G. W. F. Hegela - u format analitičkog i prognostičkog oruđa, uz dopunu hegelijanskih postavki tezama o shvatanju političkog Carla Schmitta, jedan od autora ovog rada izložio je u prethodnim radovima i monografijama koje opširno opisuju šta se podrazumeva pod dijalektikom političke mehanike. Za potrebe analitičkog objašnjenja prethodno navedenih globalnih fenomena koristićemo osnovne obrise koncepta političke mehanike i njene dijalektike te ukazati na korisnost ovog koncepta u analizi globalnih političkih tokova (Cvetićanin, 2014; 2016a; 2016b).

Koncept dijalektike političke mehanike predstavlja teorijski okvir i analitičku alatku koja posmatra društveno i političko polje kao polje u kojem društvene i političke sile uzajamno deluju jedna na drugu po principu akcije i reakcije. Sile koje deluju unutar političkog i društvenog polja zapravo predstavljaju hegelijansku tezu i antitezu koje svoje ishodište dobijaju u sintezi u kojoj se teza i antiteza ne poništavaju, već u kojoj se prepliće ono što je istorijski, društveno i politički održivo sa jedne i druge strane te se na taj način kreira novi pol koji zapravo predstavlja sintezu dva "stara" pola. Koristeći terminologiju svojstvenu tehničkim naukama, možemo reći da iz dva međusobno suprotstavljena kretanja i njihovog sudara nastaje novo kretanje, koje protokom vremena i samo dobija svoju negaciju i reakciju, te se tako niz sudara neprekidno nastavlja i odvija, usled čega političko polje nikada nije statično, već ga, naprotiv, krasi neprestana dinamika i "permanentno pulsiranje". U svemu što je društveno i političko, ovakva kretanja odvijaju se kao rivalitet i 
nadmetanje suprotstavljenih socio-političkih grupacija, a intenzitet sudara različitih polova i borbe suprotstavljenih političkih i društvenih grupacija unutar političkog polja zavisi od toga koliko ti sudari mogu biti pacifikovani postojećim pravno-političkim okvirom i institucionalnim modelima u datom društvu. Ukoliko jedno društvo, bez obzira na to da li je lokalnog, državnog, regionalnog, međunarodnog ili globalnog karaktera, ima pravno-političke i institucionalne strukture koje ne mogu da pacifikuju takve sukobe i nadmetanja socio-političkih grupa unutar njega, oni će biti jači po svom intenzitetu, a ukoliko su takve strukture razvijene, njihovo međusobno nadmetanje poprima slabiji oblik (Cvetićanin, 2017b: 118-119; Hegel, 1966).

Prethodno opisani "hegelijanski" koncept dijalektike političke mehanike bio bi nepotpun bez glasovite teze Carla Schmitta o fenomenu političkog: "Specifično političko razlikovanje na koje se mogu svesti političke radnje i motivi jeste razlikovanje prijatelja i neprijatelja" (Šmit, 2001). Ono što po Schmittu čini samu suštinu pojma političkog jeste distinkcija između "prijatelja" i "neprijatelja", pri čemu ove pojmove ne bi trebalo shvatiti kao pristrasno svrstavanje na stranu bilo koje društvene ili političke ideje ili pravca, već kao prostu deskriptivnu oznaku dinamike političkog i društvenog polja u kojem uvek de facto postoji više političkih i društvenih grupa koje se primarno bore za uticaj unutar ovog polja. Ukratko i jednostavno rečeno, politika, odnosno ono što jeste fenomen političkog prisutno je svuda gde se ljudi razvrstavaju na "prijatelje" i "neprijatelje", pri čemu se ne radi o privatnim licima u svakodnevnom značenju izraza i njihovim međusobnim odnosima i interakcijama, već o grupama "prijatelja" i "neprijatelja" kao društvenim grupama koje se međusobno razlikuju i nadmeću i čije je delovanje vezano za javni prostor. Schmittova dihotomija prijatelj/neprijatelj je stoga lišena konkretnog i određujućeg političkoideološkog sadržaja te samo govori o tome da se može razlikovati grupa "prijatelja" i grupa "neprijatelja" kao dve različite socio-političke grupe (ili više njih) sa suprotstavljenim vrednostima, interesima i(li) ciljevima. Schmitt ne određuje ni intenzitet mogućeg konflikta između "prijatelja" i "neprijatelja", te stoga princip i dihotomija prijatelj/neprijatelj opisuje tek jednu realnu tendenciju čoveka kao političkog i društvenog bića - prosto svrstavanje u grupe koje se međusobno bore za moć i uticaj, što političkom i društvenom polju daje neprestanu dinamiku. Stoga dihotomija prijatelj/neprijatelj nije ništa više nego postojanje "grupe A" i "grupe B", te je politika kao delatnost upravo i moguća isključivo u slučaju njihovog postojanja i međusobnog razlikovanja. Kada bi u svetu postojala jedna jedina, unisona politička grupa bez podeljenosti na različite "grupe A" i "grupe B", politika ne bi bila potrebna i političko ne bi bilo moguće, već bi takav beskonfliktni svet, bez potrebe donošenja političkih odluka, više ličio na Edenski vrt (Cvetićanin, 2014: 67-70). Postojanje različitih socio-političkih grupa upravo omogućava dinamiku političkog polja i političkog sveta, odnosno funkcionisanje političke mehanike koja nastaje usled njiho- 
ve međusobne interakcije. Budući da su različite socio-političke grupe u međusobnom odnosu "prijatelja" i "neprijatelja", u političkom prostoru uvek nužno deluju različite sile atrakcije i repulzije (privlačenja i odbijanja), koje proizvode političku mehaniku koja stalno "vrti” političko polje kao svojevrsni motor i održava ga vitalnim, usled čega ono nikada ne miruje, već u njemu uvek imamo dinamično smenjivanje različitih društvenih snaga, interesa, ideja i vrednosti (ibid.: 71).

Upravo kroz ovaj analitički i teorijski koncept možemo provući prethodno opisana globalna kretanja koja su obeležila posthladnoratovsku epohu i kroz prizmu prethodno opisane logike političke mehanike možemo objasniti neuspeh liberalnih politika i pokušaja implementacije liberalnog poretka širom sveta. Saglasni smo sa Mearsheimerovom tezom da je liberalni poredak od početka bio osuđen na pad jer je "posadio seme sopstvene propasti" (2019: 7), što je potpuno saglasno onome što smo prethodno konstatovali o delovanju principa dijalektike političke mehanike. Kissinger je takođe jedan od autora koji je u svojim radovima tvrdio da je istorija nezaustavljiva vrteška čiji se kraj ne može naslutiti, budući da je jedino što je večno u njoj stalna igra prekompozicije različitih međunarodnih poredaka i "koncerata" sila. Ideja širenja liberalnih vrednosti od strane države predvodnice, SAD, i njenih saveznika te integracija svih važnih svetskih aktera u kantovski foedum pacificum ipak su se ispostavile kao utopistički projekat, dajući u svetu realnih istorijskih zbivanja više za pravo (neo)realistima nego liberalima. Liberalne teze teoretičara poput Fukuyame u vreme kada je stvaranje međunarodnog liberalnog poretka tek započelo oborio je i neomarksistički teoretičar Immanuel Wallerstein (1992) zastupajući tezu da je dijalektika istorije još uvek živa i da se nužno nastavlja dinamičnim tokom.

Stvaranje ideološkog međunarodnog poretka baziranog na slobodnoj trgovini, podsticanju demokratizacije do tada nedemokratskih država i stvaranju razgranate i brojne mreže međunarodnih multilateralnih foruma i institucija nužno je upalo $u$ zamku dinamičnog kretanja istorije. Proučavanje Hegelovih teza o dijalektici istorije, pa i teza Friedricha Nietzschea o neumitnom kruženju istorije, kao i Schmittove teze da je politika moguća samo u slučaju postojanja različitih društveno-političkih grupa, dovodi do stava da sprovođenje ideološke spoljne politike nužno stvara kontraideološku reakciju. Neophodnost shvatanja realnog Zeitgeista određenog razdoblja potrebna je i iz ugla analitičara, u nastojanju da objektivno objasne političku stvarnost, i iz ugla kreatora politika, kako bi spoznali granice poželjnog i mogućeg u sprovođenju određenih političkih modela. Upravo je Hans Morgenthau u svom kapitalnom delu Politics among Nations rekao sledeće:

Politički realizam ne zahteva, ali i ne prašta, indiferentnost prema političkim idealima i moralnim principima, ali zato zahteva oštro razlikovanje između poželjnog i ostvarivog - između onoga što je poželjno na svakom mestu u svako vreme 
i onoga što je moguće pod konkretnim vremenskim i prostornim uslovima (Morgenthau, 1948).

Tvorci posthladnoratovskog liberalnog poretka prenebregnuli su upravo pomenutu granicu između poželjnog i mogućeg. Pokušaj uključivanja skoro svih država u poredak, što je neretko podrazumevalo i vojne intervencije, pokazao je neliberalne načine sprovođenja takve liberalne politike (Desch, 2008). Pored SAD, u promociji spoljne politike bazirane na vrednostima prednjačila je i EU sa željom da prevaziđe tradicionalnu politiku moći i da plasira vizije summum bonum i u zemljama članicama i u svom okruženju (Hyde-Price, 2008: 29). Iz ugla Schmittovog shvatanja političkog, na globalnom nivou dobili smo dominantnu "grupu A" koja je na krilima unipolarne posthladnoratovske strukture sveta i kolosalne moći SAD nastojala da projektuje sopstvenu Innenpolitik na globalni nivo. Ovakva politika je po pravilu stvorila naspram sebe "grupu B" koja se opirala stvaranju unisonog međunarodnog ideološkog poretka. Zemlje Bliskog istoka su na nasilan način osetile promociju liberalnog međunarodnog poretka, a zbog nepostojanja institucionalnopravnih modela kakvi postoje u razvijenim državama sukob nije bio uspešno pacifikovan, već je poprimio nasilnu formu, što empirijski vidimo u nizu oružanih sukoba koji ne jenjavaju u pomenutom regionu, kao i u terorističkim napadima marginalizovanih ekstremističkih grupa koji se dešavaju svugde po svetu. Međutim, pukotine u sprovođenju liberalne agende nisu bile svojstvene samo "periferiji” svetskog poretka, već su ozbiljni rascepi i pukotine stvoreni između suprotstavljenih grupa i u samom globalnom "centru". Jedan od autora ovog rada je u monografskoj studiji Epoha s one strane levice $i$ desnice upozorio na vidljivi rascep u svetskom sistemu i njegovoj zapadnoj hemisferi - jaz između liberalnog centra i odbačenih ideoloških margina, tj. ekstremne levice i desnice (Cvetićanin, 2008). Nesposobnost liberalnih elita da zaustave i kontrolišu ekonomske, socijalne i bezbednosne krize dovela je do porasta populističkih politika koje će, prouzrokovane demokratskim deficitima formalnog liberalnog modela, iznedriti brojne lidere i uticajne političke figure poput Donalda Trumpa, političara okupljenih oko ideje BREXIT-a, Marine Le Pen, Orbana, Erdogana, lidera nemačkog AFD itd. Stvaranje liberalnog poretka pospešilo je bazični konflikt između grupa koje baštine liberalnu ideologiju, koja je u svojoj suštini individualna zbog insistiranja na neotuđivim pravima pojedinca, i grupa kojima je više stalo do nacionalnog identiteta, samoopredeljenja i suvereniteta (Mearsheimer, 2019: 36; 2018). Nacionalni ponos je još uvek snažna emocija koja je karakteristična za sve narode sveta, bilo da se nalaze u globalnom "centru" ili na "periferiji".

Otpor liberalnom poretku došao je i od strane prirodne "geopolitičke opozicije”, tj. od Rusije i Kine. Obe države iskoristile su slobodnu trgovinu da uvećaju sopstveno bogatstvo i ekonomsku moć, što je posledično rezultiralo povećanjem 
njihove relativne moći. Međutim, zvanična Moskva i Peking nisu se odrekli svojih nacionalnih posebnosti i održali su postojeći politički sistem. Xi Jinping je istakao da kineski model predstavlja uspešnu alternativu kombinaciji liberalne demokratije i slobodnog tržišta koju su promovisale SAD. Vrtoglavi uspon Kine kroz model državnog kapitalizma ostatku sveta nudi primer kako ubrzati sopstveni razvoj uz očuvanje nacionalnih posebnosti i nezavisnosti (Brands, 2018: 61). Predsednik Rusije Putin je takođe izrazio sumnju prema liberalnom svetu, opisujući zapadni liberalizam kao moralno dekadentnu ideju i filozofiju koja bi u potpunosti unazadila rusko društvo. Prema Putinu, širenje liberalne demokratije rezultiralo je širenjem haosa i nereda po svetu, te on, za razliku od kineske "tehnokratske", predstavlja neku vrstu konzervativne kritike liberalizma shodno kojoj vrednosti liberalizma poseduju bezumni relativizam prema hrišćanskim vrednostima (ibid.).

Grupe prijatelja i grupe neprijatelja ili "grupe A" i "grupe B" na sistemskom međunarodnom nivou možemo svrstati u proponente i oponente globalnog liberalnog poretka. U tom maniru proponenti liberalnog poretka predstavljaju tezu posthladnoratovske epohe, a takmaci i rivali koji su doveli u pitanje globalni liberalni poredak na više frontova predstavljaju istorijsku antitezu. Međutim, ne smemo da upadnemo u zamku da stvari posmatramo suviše jednostavno, u prostoj ili-ili disjunkciji, već moramo ostati na terenu hegelijanske filozofije istorije koja nam je poslužila kao predložak, a shodno kojoj neka istorijska teza i neka istorijska antiteza ne ostaju hirurški odvojeni polovi, već upravo kroz sopstvenu borbu pristupaju novoj sintezi u kojoj će biti ujedinjeni elementi jednog i drugog pola koji su još uvek istorijski živi i vitalni. Stav autora ovog rada stoga jeste da trenutno dijalektički ulazimo u vreme sinteze dominantnih polova epohe (liberalnih i antiliberalnih), te će ona biti rezultanta onoga što je u trenutnom Zeitgeistu održivo i sa pola teze i sa pola antiteze, predstavljajući jednu novu-staru međunarodno-pravnu mešavinu. Stav autora ovog rada jeste da se nalazimo u predvorju kreiranja jednog realističkog svetskog multipolarnog poretka kao nove sinteze koja će u svom središtu imati cilj da obezbedi mir između država na bazi suverenih prava svake od njih. Ovaj realistični "novi svetski poredak" će uistinu biti "tanji" od nesuđenog liberalnog poretka, jer smo svedoci trke u moći između glavnih svetskih aktera i povratka bezbednosne dileme u geopolitičku realnost. Međutim, svet je nemoguće vratiti u stanje Hladnog rata kakav pamtimo od 1945. do 1990. godine pre svega zbog ireverzibilnog procesa razvoja komunikacija, tehnologije i ekonomske međuzavisnosti na čijim krilima su izazivači SAD upravo ostvarili svoj uspon. Henry Kissinger, koji je od početka imao rezerve prema liberalnom poretku, predviđao je da bi međunarodni poredak i odnosi u njemu tokom XXI veka više mogli da liče na evropski sistem država iz XVIII i XIX veka nego na rigidni hladnoratovski bipolarni poredak (1994: 10). U novom poretku se na velika vrata vraćaju u žižu međunarodnih toko- 
va bezbednosne kalkulacije - Realpolitik i Machtpolitik. Kako bi novi multipolarni sistem održao mir i stabilnost, neophodno je, u najboljem interesu svih aktera, rukovoditi se približno istim principima koji su bili sastavni deo Vestfalskog mira 1648. godine: 1) rex est imperator in regno suo, 2) cujus regio ejus religio i 3) statera virtutis. Prvi princip utvrđuje da iznad suverena ne postoji viši autoritet i da su svi suvereni nezavisni i jednaki u pravima; drugi princip se odnosi na nepovredivost teritorije i da niko nema prava da interveniše u pitanja druge države; treći princip odnosi se na sprečavanje pojave hegemona koji bi dominirao nad suverenim državama i njihovim narodima. Naravno, ovi principi nikako ne mogu biti primenjeni u starom maniru, ne samo zbog ireverzibilnog procesa razvoja komunikacija, tehnologije i ekonomske međuzavisnosti, što smo već pomenuli, već i zbog toga što je pojam "teritorije" u XXI veku drugačiji od tog pojma u XVI, XVII, XVIII ili XIX veku, jer danas uključuje i sajber-prostor, kao i potencijalne "teritorije" u svemiru oko kojih bi se velike sile mogle sporiti. No, ovi principi, redefinisani shodno realnom ustrojstvu savremene epohe sa svim njenim tehnološkim i komunikacijskim specifičnostima, mogu biti orijentir za diplomatsko međuodnošenje velikih sila u multipolarnom svetu XXI veka, u kojem ponovo, baš kao i za vreme Vestfalskog sistema, postoje različiti i heterogeni centri globalne moći. Otuda klasični moderni Vestfalski sistem država sa stanovništva današnjeg "svetskog postmodernog nereda" predstavlja mogući model nove-stare međunarodne stabilnosti. Kissinger tvrdi da je Vestfalski sistem jedan od zaista retkih funkcionalnih međunarodnih sistema koji je iznedrio stanje ravnoteže moći u međunarodnim odnosima u dužem periodu. Uspeh dugotrajnog opstanka sistema bio je u shvatanju njegove glavne realpolitičke konstante - postojanja broja država sa približno jednakom količinom moći (ibid.: 21), čemu se možda ponovo bližimo zbog opadajuće moći Sjedinjenih Država (i njenih saveznika) i uspona moći njihove "geopolitičke opozicije" (Kina, Rusija, regionalni akteri), što ove polove dovodi u svojevrsnu ravnotežu. Ova nova ravnoteža u balansu svetske moći mogla bi pogodovati opisanoj novoj sintezi između trenutnih opozitnih globalnih polova, oličenoj u novom-starom multipolarnom međunarodnom poretku nalik na onaj klasični vestfalski, koji bi trebao da dobije svoja pravila odnošenja među velikim silama primerena XXI veku. Tek kada takva pravila za multipolarni međunarodni poredak XXI veka budu uspostavljenja i kada izađemo iz perioda sadašnjeg "svetskog nereda", moći ćemo da kažemo da je XXI vek u političkom smislu zaista počeo, a do tada ćemo zapravo živeti u "dugom” XX veku, koji se očigledno nije završio padom Berlinskog zida, budući da je struktura sadašnjih međunarodnih problema i rivaliteta potpuno dvedesetovekovna, što je prosti upozoravajući znak čovečanstvu da ne ponovi iste greške kao u XX veku "dobu ekstrema" - koje su ga koštale premnogo ljudskih i materijalnih žrtava. 


\section{Zaključak}

U vremenu u kojem živimo istorijski i politički procesi uzimaju nesvakidašnje ubrzanje i događaji za koje smo do nedavno mislili da nisu mogući dešavaju se jedan za drugim, na taj način dovodeći u pitanje stereotipe nastale nakon okončanja Hladnog rata. Kolosalna moć SAD i svrstavanje saveznika uz ovu supersilu omogućilo je nakon kraja Hladnog rata stvaranje liberalnog međunarodnog poretka koji je za kreatore ovakve spoljnopolitičke agende bio garant kreiranja svetskog mira. Implementacija ideja liberalnog mira baziranog na slobodnoj trgovini između država, demokratskog mira utemeljenog na širenju liberalno-demokratskih modela političkog upravljanja širom sveta, kao i inkorporacija što većeg broja međunarodnih aktera u široku i kompleksnu mrežu međunarodnih multilateralnih foruma i institucija ipak su se pokazali kao preambiciozan poduhvat. Projektovanje sopstvene unutrašnje politike na međunarodni nivo izazvalo je globalnu kontrareakciju, što se empirijski manifestovalo u nizu političkih, socijalnih, ekonomskih i bezbednosnih kriza širom sveta. Kreatori, analitičari i teoretičari koji su verovali u održivost ideološkog liberalnog poretka baziranog na proklamovanim univerzalnim principa prevideli su da istorijski, društveni i politički tokovi, iako mogu biti usporeni u određenom periodu, nikada ne mogu biti u potpunosti zaustavljeni, na šta nisu prestajali da upozoravaju realistički teoretičari međunarodnih odnosa. Prateći misao nekolicine realističkih teoretičara istorije i međunarodnih odnosa, pokušali smo da u ovome radu, upotrebom specifičnog analitičkog oruđa - dijalektike političke mehanike - prikažemo i objasnimo političke procese koji trenutno pritiskaju strukturu međunarodnog sistema. Oslanjajući se na klasične mislioce istorije i politike - na dijalektičku metodu Hegela i dihotomiju prijatelj/neprijatelj Schmitta - prikazali smo kako političko polje permanentno "pulsira" u svojevrsnoj političkoj mehanici, što političke procese $i$ istoriju uvek iznova dinamizuje, sprečavajući ih da "zaspu" u bilo kakvom univerzalnom ideološkom miru. Ovaj univerzalni ideološki mir, bez obzira na to da li ga danas zastupaju liberali kao što su ga, na primer, za vreme Svete Alijanse u XIX veku zastupali konzervativci, jeste legitimna normativna ideja, koja, ipak, uvek mora da računa sa realnom dinamikom političkog polja, razlikujući ono što je poželjno od onog što je moguće. Svako prekoračenje ove suštinske razlike koja vekovima određuje svetsku diplomatiju, usled čega ju je jedan od njenih bardova i definisao kao "nauk mogućeg"13, vraća se kao bumerang, praveći međunarodnim odnosima više štete nego koristi.

Koristeći specifičan analitički metod dijalektike političke mehanike, opisali smo kako je pokušaj stvaranja globalnog liberalnog poretka od strane "grupe A", po

13 Bismarckovo čuveno die Lehre vom Möglichen kojim je karakterisao suštinu (visoke) politike (Poschinger, 1895-1899: 248). Temeljno tumačenje ove glasovite Bismarckove definicije politike/diplomatije u: Cvetićanin, 2016a: 200. 
prostoj logici akcije i reakcije koja uvek deluje u političkom polju, nužno izrodio globalne oponente ovom projektu u vidu "grupe B", što nije ništa drugo nego stara borba između neke istorijske teze i neke istorijske antiteze, viđena do sada bezbroj puta $\mathrm{u}$ istoriji međunarodnih odnosa, nakon koje je po pravilu nastajala neka, za određeno vreme, nova istorijska sinteza. Tako da se danas ne treba bojati da će slabljenje globalnog liberalnog poretka kojem očigledno prisustvujemo poslednjih godina značiti povratak u neku "mračnu" prošlost, već će pre podrazumevati ulazak u novu sintezu primerenu našem vremenu i njegovim realnim vektorima moći - tj. ulazak u predvorje novog multipolarnog poretka za XXI vek.

No, sasvim je legitimno izraziti dileme o posledicama dekompozicije međunarodnog liberalnog poretka, o konkretnom obliku novog multipolarnog poretka i o održivosti sinteze koju on nosi. Ostavljanje jedne ere iza nas i dolazak nove otvara mnoga pitanja - od pitanja da li će postojanje različitih i heterogenih centara moći u svetu ostaviti svet u stanju permanentne bezbednosne dileme i stalne napetosti oko pitanja mira i sukoba, sve do pitanja da li će uopšte postojanje ovakve mogućnosti okrenuti države prema suverenijem i sebičnijem odlučivanju ili ka dogovorima "za diplomatskim stolom"? Tu je i pitanje o formiranju interesnih i(li) ideoloških blokova unutar ovog multipolarnog poretka i koliko će na njihovo formiranje uticati političko i institucionalno nasleđe unipolarnog doba i ideologije globalnog liberalizma? Konačno, tu je i pitanje da li će međunarodni poredak, usled nove-stare policentričnosti, nužno "pasti” u potpuni diplomatski pragmatizam shodno kome će se interesi zemalja, u zavisnosti od tema, približavati ili udaljavati, i postoji li u takvim okolnostima mogućnost kreiranja bilo čega osim "tankog" međunarodnog poretka? Pitanja je bezbroj i na njih nije moguće jednoznačno odgovoriti a da ostanemo naučno objektivni, jer je razborita objektivnost upravo u otvorenosti spram raznih mogućnosti razvitka novog-starog multipolarnog međunarodnog poretka, čije smo klice opisali u ovom radu. No, generalni stav autora ovog rada je da će novi-stari realistični multipolarni poredak biti baziran na pragmatičnim bezbednosnim kalkulacijama i u trendu opšteg povratka značaja suvereniteta u neoklasičnom Vestfalskom obliku, primerenom našem vremenu i savremenoj strukturi sveta. Nova "postliberalna”, surovo realna, geopolitička rivalstva će bez sumnje sa sobom doneti pragmatičnu potrebu balansiranja između različitih geopolitičkih interesa kako bi novi-stari multipolarni poredak uopšte bio održiv. Rizik tog poretka će biti u tome što njegova "održivost" verovatno neće biti unapred data nekim generalnim obavezujućim globalnim aktom ili sporazumom, već će se uvek iznova morati "proizvoditi" uspostavljanjem pragmatičnih "koalicija interesa" koje mogu biti u ravnoteži, ali koje mogu biti i u disbalansu i sledstveno tome uzrokovati veće ili manje međunarodne krize, baš onako kako je bivalo uvek u istoriji međunarodnih odnosa kada smo imali policentrični međunarodni sistem, koji je po definiciji osuđen na 
"pulsiranje" između stabilnosti i nestabilnosti. Vreme pred nama će upravo pokazati umeće međunarodnih aktera da u novonastalim "policentričnim" međunarodnim okolnostima utišaju sopstvene ideološke diskurse i nađu meru u promovisanju sopstvenih interesa kako bi čuli i "drugu stranu" te dali prednost diplomatskom pragmatizmu nad bilo kojom rigidnom i jednostranom ideologijom, radeći tako u korist stabilnosti i ravnoteže jednog novog multipolarnog sveta, koji pred našim očima nastaje. U ovom novom-starom, realističnom, multipolarnom svetu ključan će biti osećaj mere glavnih aktera, koji će sada, baš kao i u najvećem delu istorije međunarodnih odnosa, biti glavni resurs realistične i pragmatične diplomatije.

\section{LITERATURA}

\section{Knjige i članci}

Brands, Hal. 2018. Democracy vs Authoritarianism: How Ideology Shapes Great-Power Conflict. Survival, 60(5): 61-114.

Brands, Hal, Edelman, Eric. 2017. America and the Geopolitics of Upheaval. The National Interest. July-August.

Cvetićanin, Neven. 2008. Epoha s one strane levice i desnice. Službeni glasnik, Institut društvenih nauka. Beograd.

Cvetićanin, Neven. 2014. Politička mehanika i njena dijalektika - u susret jednoj novoj teoriji politike. Theoria, 1: 63-85.

Cvetićanin, Neven. 2016a. Državništvo modernog doba. Arhipelag, Institut društvenih nauka. Beograd.

Cvetićanin, Neven. 2016b. Politička mehanika i veština državništva. Arhipelag, Institut društvenih nauka. Beograd.

Cvetićanin, Neven. 2017a. Ubrzanje istorije i nastavak "dugog" 20. veka, u: Goran Bašić, Mirjana Rašević (ur.): "Ukalupljivanje” ili prekoračenje granica: Društvene nauke u savremenom dobu. Institut društvenih nauka. Beograd: 239-263.

Cvetićanin, Neven. 2017b. Kuda ide svet? Analiza društveno-političkih procesa koji opredeljuju globalna zbivanja na početku 21. veka, u: Veselin Vuković et al. (ur.): Globalizacija i izolacionizam. Centar za ekonomska istraživanja Instituta društvenih nauka. Beograd: 116-130.

Desch, Michael C. 2008. America's liberal illiberalism: The ideological origins of overreaction in US foreign policy. International Security, 32(3): 7-43.

Dinan, Dezmon. 2009. Sve bliža Unija - uvod u evropsku integraciju. Službeni glasnik. Beograd.

Dinan, Dezmon. 2010. Menjanje Evrope - Istorija Evropske unije. Službeni glasnik. Beograd. 
Doyle, Michael. 1983. Kant, liberal legacies, and foreign affairs. Philosophy \& Public Affairs, 12(3): 205-235.

Doyle, Michael. 1986. Liberalism and world politics. The American Political Science Review, 80(4): 1151-1169.

Ejdus, Filip. 2012. Međunarodna bezbednost: teorije, sektori i nivoi. Službeni glasnik. Beograd.

Friedman, Thomas. 2000. The Lexus and the Olive Tree. Anchor Books. New York.

Fukuyama, Francis. 1989. The end of history?. The National Interest, (16): 3-18.

Hegel, Georg Wilhelm Fridrich. 1966. Filozofija povijesti. Naprijed. Zagreb.

Hendrickson, David. 1994. The recovery of internationalism. Foreign Affairs, 73(5): 26-43.

Hobsbaum, Erik. 2004. Doba ekstrema. Dereta. Beograd.

Hyde-Price, Adrian. 2008. A 'tragic actor'? A realist perspective on 'ethical power Europe'. International Affairs, 84(1): 29-44.

Ikenberry, John. 2018. The end of liberal international order?. International Affairs, 94(1): 7-23.

Keohane, Robert, Nye, Joseph. 1977. Power and Interdependence: World Politics in Transition. Little Brown. Boston.

Kirchick, James. 2017. The End of Europe: Dictators, Demagogues, and the Coming Dark Age. Yale University Press. New Haven i London.

Kissinger, Henry. 1994. Diplomacy. Simon \& Schuster. New York.

Krauthammer, Charles. 1990. The Unipolar Moment. Foreign Affairs, 70(1): 23-33.

Marks, Karl. 1964. Kapital. Kultura. Beograd.

Mearsheimer, John. 1990. Back to the Future: Instability in Europe after the Cold War. International Security, 15(1): 5-56.

Mearsheimer, John. 1994. The False Promise of International Institutions. International Security, 19(3): 5-49.

Mearsheimer, John. 2018. The Great Delusion: Liberal Dreams and International Realities. Yale University Press. New Haven.

Mearsheimer, John. 2019. Bound to Fail: The Rise and Fall of the Liberal International Order. International Security, 43(4): 7-50.

Miršajmer, Džon. 2017. Tragedija politike velikih sila. Udruženje za studije SAD u Srbiji i Čigoja štampa. Beograd.

Morgenthau, Hans. 1948. Politics Among Nations: The Struggle for Power and Peace. Alfred A. Knopf, Inc. New York.

Oatley, Thomas. 2015. International political economy. Routledge. New York i London.

O’Neal, John R., Russet, Bruce M. 1997. The Classical Liberals Were Right: Democracy, Interdependence, and Conflict, 1950-1985. International Studies Quarterly, 41(2): 267-293. 
Patrick, Stewart. 2013. The Evolving Structure of World Politics, 1991-2011, u: Geir Lundestad (ur.): International Relations Since the End of the Cold War-New and Old Dimensions. Oxford University Press. Oxford: 16-41.

Poschinger, Heinrich. 1895-1899. Fürst Bismarck: neue Tischgespräche und Interviews, sv. I. Deutsche Verlags-Anstalt. Stuttgart.

Schimmelfennig, Frank, Sedelmeier, Ulrich. 2004. Governance by conditionality: EU rule transfer to the candidate countries of Central and Eastern Europe. Journal of European Public Policy, 11(4): 661-679.

Smith, Adam. 1952. Istraživanje prirode i uzroka bogatstva naroda. Kultura. Zagreb.

Šmit, Karl. 2001. Pojam političkog, u: Slobodan Samardžić (ur.): Karl Šmit i njegovi kritičari. Filip Višnjić. Beograd.

Wallerstein, Immanuel. 1992. Geopolitics and Geoculture: Essays on the changing world system. Cambridge University Press. Cambridge.

Waltz, Kenneth. 2000. Structural realism after the Cold War. International Security, 25(1): 5-41.

Wohlforth, William. 1999. The stability of a unipolar world. International Security, 24(1): 5-41.

Wolfers, Arnold. 1962. Discord and Collaboration: Essays on International Politics. Johns Hopkins University Press. Baltimore.

\section{Izvori i dokumenta}

Bush, George H. W. 1990. "Address before a Joint Session of the Congress on the Persian Gulf Crisis and the Federal Budget Deficit", 11. 9. Dostupno na: https://bush 41library.tamu.edu/archives/public-papers/2217 (pristupljeno 13. 11. 2020).

Cvetićanin, Neven. 2016. Povratak suvereniteta. Politika, 23. 10. Dostupno na: http:// www.politika.rs/sr/clanak/366201/Pogledi/Povratak-suvereniteta (pristupljeno 26. 11. 2020).

European Council. 1993. Conclusion of the Presidency, Copenhagen, 21-22. 6., General Secretariat of the Council, Brussels.

https://data.worldbank.org/indicator/NY.GDP.MKTP.CD?most_recent_value_desc=true (pristupljeno 25. 11.2020).

https://www.statista.com/statistics/262742/countries-with-the-highest-military-spending/ (pristupljeno 25. 11. 2020).

Poland delays abortion ban as nationwide protests continue. 2020. The Guardian, 3. 11. Dostupno na: https://www.theguardian.com/world/2020/nov/03/poland-stalls-abortion-ban-amid-nationwide-protests (pristupljeno 26. 11. 2020).

To Paris, U.S. Looks Like a 'Hyperpower'. 1999. The New York Times, 5. 2. Dostupno na: https://www.nytimes.com/1999/02/05/news/to-paris-us-looks-like-a-hyperpower.html (pristupljeno 9. 11. 2020). 
Viktor Orban: Era of 'liberal democracy' is over. 2018. Deutsche Welle, 10. 5. Dostupno na: https://www.dw.com/en/viktor-orban-era-of-liberal-democracy-is-over/a-43732540 (pristupljeno 26. 11. 2020).

White House. 1994. A National Security Strategy of Engagement and Enlargement, The White House, Washington DC. Dostupno na: https://nssarchive.us/wp-content/ uploads/2020/04/1994.pdf (pristupljeno 17. 11. 2020).

\author{
Neven Cvetićanin, Marko Mandić \\ THE TWILIGHT OF THE LIBERAL INTERNATIONAL ORDER, \\ THE DIALECTIC OF POLITICAL MECHANICS \\ AND THE NEW WESTPHALIAN SYSTEM FOR THE 21st CENTURY
}

\begin{abstract}
Summary
The authors of this paper offer an overview and analysis of the rise and fall of the liberal international order that emerged after the end of the Cold War and along with the rising power of the United States. The foreign policy agenda of the post-Cold War sole superpower was guided by the idea of creating a global order based on the ideology of liberalism, which incorporates theories of liberal peace, democratic peace and neoliberal institutionalism. The establishment of a liberal order has been accompanied by numerous political, social, economic and security crises. The current era is characterized by the rise of the relative power of global actors, primarily China and Russia, as the main challengers to the world domination of the United States, geopolitical revisionism and ideological struggle around the world. The authors of this paper use the dialectic of political mechanics as a method that relies on the teachings of Friedrich Hegel on the dialectic of history and Carl Schmitt on the phenomenon of the political. The authors advocate the view that the political field "permanently pulsates", which, in everything that is social and political, necessarily creates action and reaction.
\end{abstract}

Keywords: Liberal International Order, Dialectic of Political Mechanics, Friend/Enemy, International Relations, Westphalian System

Neven Cvetićanin je viši naučni saradnik na Institutu društvenih nauka u Beogradu. Marko Mandić je istraživač pripravnik na Institutu društvenih nauka u Beogradu. Kontakti:

Neven Cvetićanin, Institut društvenih nauka, Kraljice Natalije 45 (bivša: Narodnog fronta), 11000 Beograd, Srbija. E-mail: nevencveticanin@gmail.com

Marko Mandić, Institut društvenih nauka, Kraljice Natalije 45 (bivša: Narodnog fronta), 11000 Beograd, Srbija. E-mail: mandic1612@gmail.com 